\title{
Effect of salt and temperature stresses on survival and infectivity of Heterorhabditis spp. IJs
}

\author{
Michelle M. Finnegan ${ }^{1}$, Martin J. Downes ${ }^{1}$, Myra O'Regan ${ }^{2}$ \\ and Christine T. GRIFFIN ${ }^{1}$ \\ ${ }^{1}$ Department of Biology, NUI Maynooth, Maynooth, Co. Kildare; ${ }^{2}$ Department of Statistics, Trinity College, Dublin, \\ Ireland
}

Accepted for publication: 6 April 1998

\begin{abstract}
Summary - Heterorhabditis is frequently found in coastal sandy soils where it may experience both high salinity and high temperatures. We tested the ability of infective juveniles (IJs) of three taxonomic groups of Heterorhabditis to infect insects in saline sand. We also tested whether salinity (sea water) affected the IJs' ability to tolerate elevated temperatures in aqueous suspension and in sand. IJs of all three taxonomic groups killed Galleria mellonella in saline sand (25.6\% insects killed), but at a lower level than in non-saline sand (96.5\% insects killed). Exposure of IJs in sand to high temperature reduced their ability to kill G. mellonella at $20^{\circ} \mathrm{C}$; heating IJs in saline sand reduced $G$. mellonella mortality to a lesser extent $\left(25.6 \%\right.$ at $20^{\circ} \mathrm{C}, 18.3 \%$ at $\left.39^{\circ} \mathrm{C}\right)$ than heating in non-saline sand $(96.5 \%$ at $20^{\circ} \mathrm{C}, 17.5 \%$ at $39^{\circ} \mathrm{C}$ ). In aqueous suspension, IJs of the North-West European and Irish types of Heterorhabditis tolerated high temperature better in sea water (at least $95 \%$ survived $1 \mathrm{~h}$ at $39^{\circ} \mathrm{C}$ ) than in distilled water (none survived $1 \mathrm{~h}$ at $38^{\circ} \mathrm{C}$ ). H. bacteriophora $^{\circ}$ was more temperature tolerant: survival and subsequent infectivity of IJs was unaffected by temperature up to $39^{\circ} \mathrm{C}$ in either medium. It was concluded that high salinity (sea water) reduces the ability of Heterorhabditis IJs to infect, but improves their tolerance of high temperature.
\end{abstract}

Résumé - Effets des chocs dus à la salinité et à la température sur la survie et l'infestivité des juvéniles infestants d' Heterorhabditis spp. - Les Heterorhabditis sont fréquemment rencontrés dans les sols sableux côtiers où ils peuvent être soumis à des salinités et des températures élevées. Nous avons testé la capacité des juvéniles infestants (IJs) de trois groupes taxinomiques d' Heterorhabditis à infester des insectes dans du sable salé. Nous avons aussi cherché à savoir si la salinité (eau de mer) affecte la capacité des IJs à tolérer des températures élevées, soit en suspension aqueuse, soit dans du sable. Les IJs des trois troupes taxinomiques tuent les Galleria mellonella dans le sable salé, mais à un taux plus faible que dans le sable non salé (25,6 contre 96,5\% des insectes tués). L'exposition des IJs dans du sable à des températures élevées réduit leur capacité à tuer G. mellonella à $20^{\circ} \mathrm{C}$; le chauffage des IJs dans du sable salé réduit la mortalité des $G$. mellonella dans un moindre mesure $\left(25,6\right.$ à $20^{\circ} \mathrm{C}$ contre $18,3 \%$ à $\left.39^{\circ} \mathrm{C}\right)$ que dans du sable non salé $\left(96,5 \%\right.$ à $20^{\circ} \mathrm{C}$ contre 17,5\% à $\left.39^{\circ} \mathrm{C}\right)$. En suspension aqueuse, les IJs des types Europe du nord-ouest et d'Irlande tolèrent mieux les températures élevées dans l'eau de mer (au moins $95 \%$ survivent $1 \mathrm{~h}$ à $39^{\circ} \mathrm{C}$ ) que dans l'eau distillée (aucune survie après $1 \mathrm{~h}$ à $38^{\circ} \mathrm{C}$ ). H. bacteriophora montre la meilleure tolérance à la température: la survie et l'infestivité ultérieures des IJs ne sont pas affectées par la température jusqu'à $39^{\circ} \mathrm{C}$ dans l'un et l'autre milieux. Il en est conclu que les salinités élevées (eau de mer) réduisent la capacité d'infestation des IJs d' Heterorhabditis, mais améliorent leur tolérance aux températures élevées.

Keywords: entomopathogenic nematode, environmental stress, heat tolerance, Heterorhabditis, salinity, salt tolerance, temperature.

Entomopathogenic nematodes (Heterorhabditis spp. and Steinernema spp.) have considerable potential for the biocontrol of insect pests (Kaya \& Gaugler, 1993). The transmission stage is a specialised third stage juvenile, the infective juvenile (IJ) which carries cells of a symbiotic insect-killing bacterium (Photorhabdus luminescens in Heterorhabditis spp.) in its intestine. On entry into the host's haemocoel, the nematode releases the bacteria which proliferate, killing the host by septicaemia. The IJs, like the dauer juvenile of Caenorhabditis elegans, does not feed and is more resistant than other stages to environmental stresses.

Griffin et al. (1994b) showed that Heterorhabditis was halotolerant. IJs survived prolonged storage in sea water as well as or better than in distilled water, and remained infective for up to nineteen weeks. Griffin et al. (1994b) suggested that Heterorhabditis IJs might be transported between coastal sites by sea currents. In that study, infectivity was tested in a non-saline medium. Thurston et al. (1994) reported that the infectivity of $H$. bacteriophora was not reduced in saline sand with an electroconductiv- 
ity of $16-32 \mathrm{dS} / \mathrm{m}$ when the salt used was $\mathrm{CaCl}_{2}$ or $\mathrm{KCl}$, but $\mathrm{NaCl}$ did reduce infectivity.

Temperature is one of the most important factors affecting entomopathogenic nematodes (e.g., Kaya, 1990; Griffin, 1993). The effects of temperature on infectivity and on long-term persistence are well documented (e.g., Molyneux, 1985, 1986; Griffin \& Downes, 1991; Kung et al., 1991), but lethal temperature limits have received less attention. IJs may need to survive exposure to temperatures higher than those at which infection can occur, at least for short periods of the day, especially in warmer climatic zones or following foliar application. IJs of HP88, a Utah strain of Heterorhabditis bacteriophora, were all killed by short (1-2 h) exposure to $40^{\circ} \mathrm{C}$, and their viability was reduced at $37^{\circ} \mathrm{C}$ (Glazer et al., 1996; Shapiro et al., 1996). Some Israeli isolates of H. bacteriophora and of $H$. megidis were considerably more heat tolerant than HP88 at both 37 and $40^{\circ} \mathrm{C}$ (Glazer et al., 1993, 1996; Shapiro et al., 1996).

Heterorhabditids are frequently found in sandy coastal soils (Hara et al., 1991; Amarasinghe et al., 1994; Griffin et al., 1994a). Poinar (1993) cited this amongst the evidence for the origin of the genus in an arenicolous marine environment. The reason for this association with coastal sands is not clear, but one consequence is that in soils close to the sea, nematodes may encounter elevated levels of salinity and also of temperature. Sandy soils are more prone to heating than soils with better water holding capacity. The sites at which we have recovered Heterorhabditis in northern and central Europe typically have short vegetation, without much shading tree or shrub cover (Griffin et al., 1994a, 1999), increasing the vulnerability of such soils to heating. In their natural environment, organisms are exposed to a variety of stresses simultaneously, and their viability is determined by the interaction of these factors. Here we test the effect of salinity on the ability of IJs of each of the three European types of Heterorhabditis to tolerate elevated temperatures, both in aqueous suspension and in sand. We also test their ability to infect insects in sand moistened with undiluted sea water.

\section{Materials and methods}

\section{SOURCE AND MAINTENANCE OF NEMATODES}

Six Heterorhabditis isolates, two of each of three taxonomic groups, were used (Table 1). Nematodes were cultured at $20^{\circ} \mathrm{C}$ in late instar larvae of the wax-moth $\mathrm{Gal}$ -
Table 1. Origin and taxonomic position of the Heterorhabditis isolates used in the study

\begin{tabular}{|c|c|c|c|}
\hline Code & Species/Type & Origin & Source \\
\hline EU222 & H. bacteriophora & $\begin{array}{l}\text { Debrecen, } \\
\text { Hungary }\end{array}$ & Maynooth \\
\hline EU185 & H. bacteriophora & $\begin{array}{l}\text { Kesckemet, } \\
\text { Hungary }\end{array}$ & Maynooth \\
\hline UK211 & North-west European & $\begin{array}{l}\text { South coast } \\
\text { of England }\end{array}$ & Hominick $^{*}$ \\
\hline HF85 & North-west European & $\begin{array}{l}\text { Flevopolder, } \\
\text { Netherlands }\end{array}$ & Westerman** \\
\hline W48 & Irish & $\begin{array}{l}\text { South coast } \\
\text { of Wales }\end{array}$ & Maynooth \\
\hline M170 & Irish & $\begin{array}{l}\text { North-west coast } \\
\text { of Ireland }\end{array}$ & Maynooth \\
\hline
\end{tabular}

* Dr W.M Hominick, International Institute for Parasitology.

*** Ir Paula Westerman, Friesland College of Agriculture, The Netherlands.

leria mellonella. IJs were harvested in modified White traps, washed by sedimentation in three changes of tap water and used within two weeks of harvesting.

\section{EFFECT OF HIGH TEMPERATURES ON IJS IN AQUEOUS SUSPENSION}

Suspensions of $400 \mathrm{IJ} / \mathrm{ml}$ were prepared in sea water (from Sandycove, Co. Dublin; electroconductivity 54 $\mathrm{dS} / \mathrm{m}$ ) or distilled water. Suspensions were prepared 2 days before exposure to high temperatures took place. Eppendorf tubes containing aliquots of $1 \mathrm{ml}$ suspension were suspended in water baths at 20, 32, 33, 34, 35, 36, 37, 38 and $39^{\circ} \mathrm{C}$ for $1 \mathrm{~h}$. Temperature was monitored using a thermistor probe connected to a Grant Squirrel data logger immersed in an Eppendorf containing $1 \mathrm{ml}$ distilled water; it reached the bath temperature within $5 \mathrm{~min}$. Dissolved oxygen levels were recorded in saline and distilled water, with and without nematodes, at the start and end of a $1 \mathrm{~h}$ incubation at 20,37 and $39^{\circ} \mathrm{C}$, using a micro oxygen sensor (UMS, Kaltenordheim, Germany). Oxygen declined by up to $28 \%$ (sea water at $39^{\circ} \mathrm{C}$ ) of starting level (saturation). After $1 \mathrm{~h}$, tubes were removed from the water baths and allowed to return to room temperature (c. $23^{\circ} \mathrm{C}$ ). There were two tubes for each treatment (isolate/temperature/medium). One set of tubes was examined immediately: IJs in the other set of tubes were washed by sedimentation three times in distilled water and left to recover in distilled water for 2 days at $20^{\circ} \mathrm{C}$ prior to examination. The numbers of living and dead IJs were counted. 
Nematodes which failed to respond to probing with a fine glass rod were counted as dead.

For five of the test temperatures $(20,33,35,37$ and $39^{\circ} \mathrm{C}$ ) the infectivity of the surviving IJs, washed and unwashed, was assessed. Infectivity was assessed as the ability to kill Galleria mellonella larvae and as the proportion of nematodes that established in the killed insects. A late instar G. mellonella larva was placed in a $2.5 \mathrm{~cm}$ diam. Petri dish which was then filled with moist sand (heat sterilized silver sand moistened with $8 \%$ tap water $(\mathrm{w} / \mathrm{w})$ ). Ten IJs were picked out by reference to preselected locations in a gridded dish and added to the sand in a minimum of water $(c .40 \mathrm{ml})$. Controls received water without nematodes. The assay dishes (five per treatment) were incubated at $20^{\circ} \mathrm{C}$ for 4 days. The insects were removed from the sand, washed in tapwater and patted dry with paper towelling to remove IJs adhering to the cuticle. They were returned to $20^{\circ} \mathrm{C}$ and dissected after a further 2-3 days. The number of first generation female nematodes was taken as representative of the number of IJs that had entered.

The experiment was repeated on three successive days using the same batches of IJs.

\section{EFFECT OF HIGH TEMPERATURE ON IJS IN SAND}

Flat-bottomed glass tubes $(50 \mathrm{~mm}$ high $\times 11 \mathrm{~mm}$ int. diam.) were filled with $c$. $3.5 \mathrm{~g}$ moistened sand. The sand (washed, sterilised sea sand of particle diameter 170$250 \mu \mathrm{m})$ was moistened $(8 \% \mathrm{w} / \mathrm{w})$ with either sea water or distilled water. To each vial of this saline sand or nonsaline sand was added $100 \mathrm{ml}$ of IJs suspension containing 100 IJs in, respectively, either sea water or distilled water. The tubes were capped and suspended in water baths at 20,37 or $39^{\circ} \mathrm{C}$ for $1,2,4,6$ or $24 \mathrm{~h}$. Temperature within the sand was monitored by means of a thermistor probe inserted through the lid of a vial containing sand without IJs and attached to a Grant Squirrel data logger. The timing of the incubation period started when the test temperature was reached (which was within 5 min of immersion in the water bath).

Following incubation, the vials were allowed to return to room temperature $\left(c .23^{\circ} \mathrm{C}\right)$. The infectivity of the nematodes in the sand was tested by baiting for 2 days at $20^{\circ} \mathrm{C}$ with G. mellonella larvae. Ten vials per treatment were baited immediately, while another ten vials were left for 2 days at $20^{\circ} \mathrm{C}$ before baiting. One late instar G. mellonella larva was placed on the sand surface in each vial. It was then covered with saline or non-saline sand, as appropriate, to the top of the tube. After 2 days at $20^{\circ} \mathrm{C}$, the insects were removed from the sand, washed in tap water and patted dry with paper towelling to remove IJs adhering to the cuticle. They were then incubated at $20^{\circ} \mathrm{C}$ for a further 3-4 days before dissection. The number of first generation females was taken as representative of the number of IJs that had entered. Note was taken of the appearance of the cadaver. Each of the Photorhabdus luminescens strains carried by the isolates tested here imparts a characteristic colour (yellow, purple or red, depending on the isolate) to the cadaver, which also develops a gummy consistency. Control tubes containing saline or non-saline sand without nematodes were incubated at 20,37 or $39^{\circ} \mathrm{C}$ for $24 \mathrm{~h}$ and baited with $G$. mellonella as above.

The six isolates of the study were divided into two isolate sets (A and B). Each isolate set contained one isolate of each of the three taxonomic groups. The sand experiment was conducted twice, using a different isolate set on each occasion. The isolates of $H$. bacteriophora and the NWE and Irish types of Heterorhabditis were, respectively: EU222, HF85 and M170 in Set A, and EU185, UK211 and W48 in Set B.

\section{STATISTICAL ANALYSIS}

An analysis of variance was carried out on the data. For the analysis of G. mellonella mortality, the dependent variable was the $\operatorname{logit}$ function $=\log \left(\frac{p}{1-p}\right)$ where $p$ was the proportion of insects that died. A suitable small constant was added to the numerator and denominator in the cases where $p=0$ or 1 .

\section{Results}

\section{EXPOSURE TO HIGH TEMPERATURES IN AQUEOUS SUSPENSION}

\section{Nematode survival}

IJs of both of the H. bacteriophora isolates (EU185 and EU222) survived one hour at all temperatures up to and including $39^{\circ} \mathrm{C}$ without significant mortality, both in distilled water and in sea water (Table 2). At least $90 \%$ of the IJs of the NWE and Irish isolates survived an hour at $37^{\circ} \mathrm{C}$ in distilled water but none survived at $38^{\circ} \mathrm{C}$. However, in sea water, at least $95 \%$ of the IJs survived at $39^{\circ} \mathrm{C}$ (Table 2).

\section{Mortality of bait insects}

The infectivity of IJs surviving the temperature treatments was tested against G. mellonella. Ability to kill 
Table 2. Percentage of infective juveniles of Heterorhabditis spp. alive following exposure to various temperatures for $1 \mathrm{~h}$ in aqueous suspension (sea water or distilled water)

\begin{tabular}{|c|c|c|c|c|c|c|c|c|c|c|c|c|}
\hline \multirow{3}{*}{$\begin{array}{l}\text { Temperature } \\
\left({ }^{\circ} \mathrm{C}\right)\end{array}$} & \multicolumn{4}{|c|}{ H. bacteriophora } & \multicolumn{4}{|c|}{ NWE type Heterorhabditis } & \multicolumn{4}{|c|}{ Irish type Heterorhabditis } \\
\hline & \multicolumn{2}{|c|}{ EU222 } & \multicolumn{2}{|c|}{ EU185 } & \multicolumn{2}{|c|}{ UK211 } & \multicolumn{2}{|c|}{ HF85 } & \multicolumn{2}{|c|}{ M170 } & \multicolumn{2}{|c|}{ W48 } \\
\hline & Dist & Sea & Dist & Sea & Dist & Sea & Dist & Sea & Dist & Sea & Dist & Sea \\
\hline 20 & 99.2 & 98.8 & 99.3 & 99.7 & 99.3 & 99.8 & 98.9 & 97.7 & 98.5 & 98.5 & 99.2 & 99.4 \\
\hline 32 & 99.5 & 99.3 & 98.9 & 99.6 & 99.1 & 99.8 & 98.8 & 98.1 & 98.4 & 97.5 & 99.3 & 99.3 \\
\hline 33 & 99.3 & 99.3 & 99.8 & 99.3 & 99.3 & 99.8 & 98.1 & 97.0 & 97.9 & 98.8 & 98.7 & 99.3 \\
\hline 34 & 99.3 & 98.9 & 99.5 & 99.8 & 99.3 & 99.4 & 97.6 & 97.2 & 98.3 & 98.3 & 98.8 & 99.2 \\
\hline 35 & 99.3 & 98.6 & 99.2 & 99.5 & 99.0 & 99.4 & 97.5 & 96.9 & 97.8 & 97.9 & 92.9 & 99.3 \\
\hline 36 & 98.8 & 98.7 & 99.0 & 99.3 & 99.0 & 99.3 & 97.3 & 96.3 & 97.5 & 96.9 & 94.4 & 98.6 \\
\hline 37 & 99.3 & 98.9 & 99.0 & 99.4 & 98.5 & 99.6 & 98.3 & 97.2 & 95.5 & 97.8 & 92.1 & 97.9 \\
\hline 38 & 97.9 & 99.3 & 98.4 & 99.3 & 0 & 99.3 & 0 & 96.7 & 0 & 97.7 & 0 & 99.0 \\
\hline 39 & 96.7 & 98.7 & 99.1 & 99.1 & 0 & 96.1 & 0 & 94.9 & 0 & 95.8 & 0 & 95.3 \\
\hline
\end{tabular}

Data are mean of three replicates.

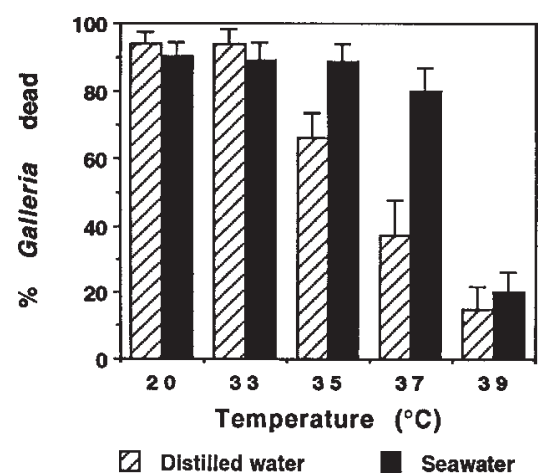

Fig. 1. Mean percentage mortality of Galleria mellonella larvae exposed in sand at $20^{\circ} \mathrm{C}$ to Heterorhabditis IJs that had previously been heated for $1 \mathrm{~h}$ at temperatures ranging from 20 to $39^{\circ} \mathrm{C}$. (Means are of six nematode isolates, both washed and unwashed treatments. Bars $=$ SEM).

G. mellonella was reduced by prior exposure to high temperatures $\left(35^{\circ} \mathrm{C}\right.$ and above), particularly when the exposure was in distilled water (Fig. 1). Mortality of control insects (no nematodes) was in all cases zero. High levels of G. mellonella mortality occurred in many of the nematode treatments, especially at lower temperatures $\left(20-35^{\circ} \mathrm{C}\right.$ inclusive) where $100 \%$ mortality was frequently recorded. This was true for all isolates except EU185, where the maximum mortality in any treatment was $93 \%$ (detailed results not shown). Due to the frequent occurrence of $100 \%$ mortality, these data were not as useful for discriminating between treatments as was the proportion of nematodes that established in the bait insects.

\section{Establishment of nematodes in bait insects}

Up to $60 \%$ of IJs established in the bait insects, but this proportion was considerably lower in several instances, especially for the Irish and NWE isolates following exposure to high temperatures (Fig. 2). An analysis of variance was carried out on these data. The independent variables were: temperature, salinity (distilled or sea water), washing (IJs washed or not washed after heating) and isolate (six isolates). The most important effects $(P<0.0001)$ identified in this analysis were the interaction terms temperature $\times$ salinity and temperature $\times$ isolate and the main effect washing. Each of these significant effects will now be discussed.

Temperature by salinity. At higher temperatures (35, 37 and $39^{\circ} \mathrm{C}$ ), high salinity (sea water) tended to improve nematode viability (as assessed by subsequent ability to infect and establish in G. mellonella larvae), while at lower temperatures $\left(20\right.$ and $33^{\circ} \mathrm{C}$ ) the trend was reversed (Fig. 2). The largest effect of salinity occurred at $37^{\circ} \mathrm{C}$ : IJs that had been exposed to $37^{\circ} \mathrm{C}$ in sea water were almost three times more infective to G. mellonella than those that had been exposed in distilled water: $25 \%$ as against $9 \%$ nematodes established in the insects.

Temperature by isolate. The isolates differed in their response to temperature. For each of the NWE and Irish group isolates there was a marked effect of temperature: high numbers of nematodes established following exposure to the two lower temperatures $\left(20\right.$ and $33^{\circ} \mathrm{C}$ ); lower numbers established following exposure to $35^{\circ} \mathrm{C}$ and above; in the $39^{\circ} \mathrm{C}$ treatment, numbers of nematodes 

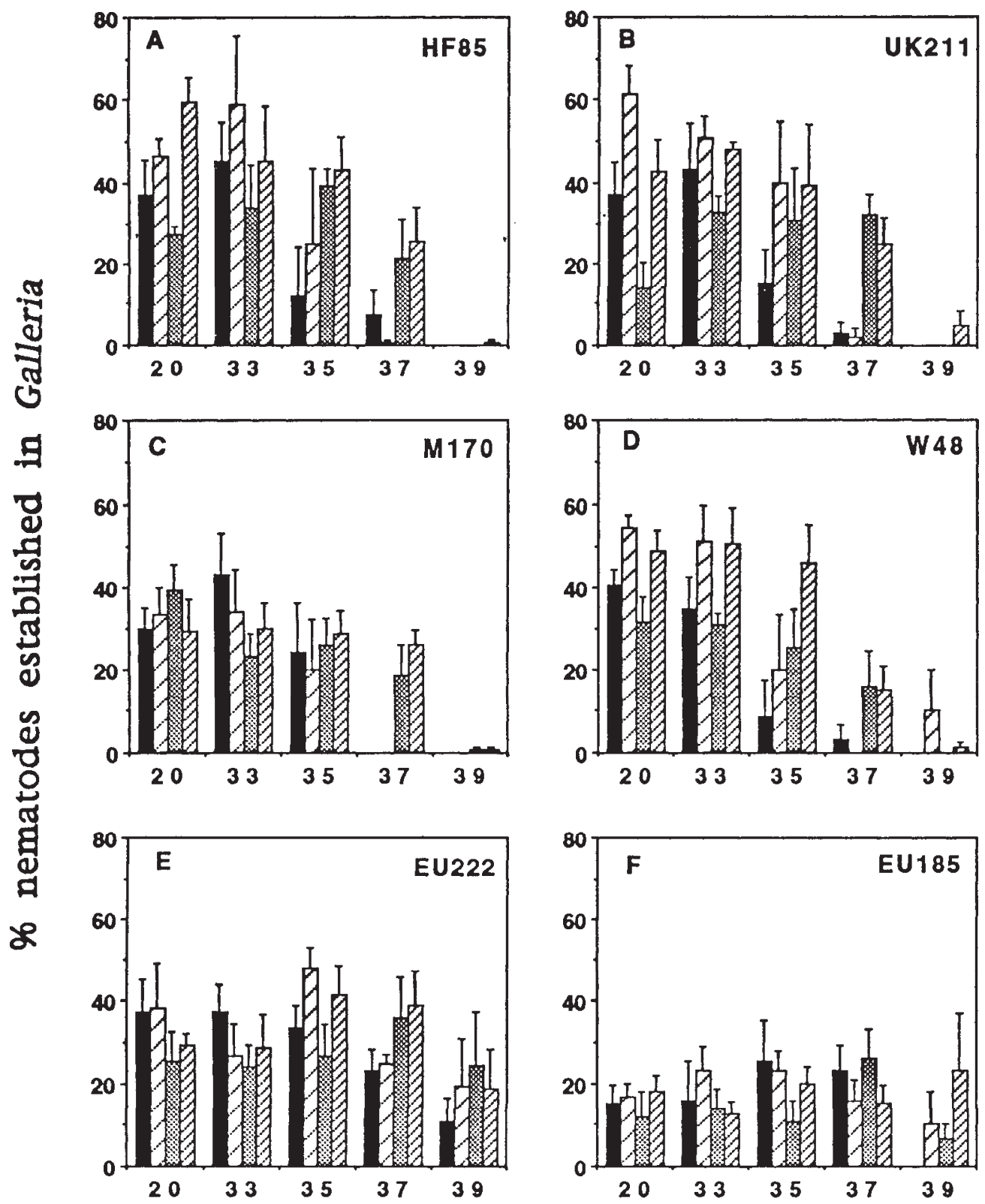

Temperature $\left({ }^{\circ} \mathrm{C}\right)$

\section{Dlstllled water $\square$ Distilled water (washed) Seawater $\square$ Seawater (washed)}

Fig. 2. The percentage of IJs of six isolates of Heterorhabditis that established in Galleria mellonella larvae during two days in sand at $20^{\circ} \mathrm{C}$. IJs in sea water or in distilled water had previously been exposed to five temperatures for $1 \mathrm{~h}$. Infectivity was tested either immediately or after washing in distilled water. A: NWE type HF85; B: NWE type UK211; C: Irish type M170; D: Irish type W48; E: H. bacteriophora EU222; F: H. bacteriophora EU185. Bars = SEM. 
established were very low (Fig. 2 A-D). Temperature had much less of an effect on the two $H$. bacteriophora isolates (EU222 and EU185) (Fig. 2 E, F).

Washing. Washing the IJs following temperature treatment resulted in a higher proportion of the nematodes becoming established in the test insects: $27 \%$ of the washed nematodes established, compared to $21 \%$ of the unwashed nematodes (Fig. 2).

\section{EXPOSURE TO HIGH SALINITY AND HIGH TEMPERATURES IN MOIST SAND}

In this experiment, IJs remained in the sand throughout the high temperature treatment and subsequent baiting with G. mellonella, and thus there is no direct measure of IJs survival. Results of the baiting are given both as G. mellonella mortality and as the proportion of nematodes that established.

\section{Mortality of bait insects}

Following $20^{\circ} \mathrm{C}$ exposure, IJs in non-saline sand (sand moistened with distilled water) killed nearly four times as many G. mellonella as IJs in saline sand (moistened with sea water) (Fig. 3A). Heating IJs to 37 or $39^{\circ} \mathrm{C}$ in nonsaline sand greatly reduced their ability to kill G. mellonella while the killing power of IJs in saline sand was only slightly affected by these temperatures (Fig. 3A). This trend (high bait insect mortality in non-saline, $20^{\circ} \mathrm{C}$ exposed sand compared to other salinity-temperature combinations) was found for every combination of the other factors tested (i.e., for each of the six nematode isolates, at each exposure time, and in sand baited immediately after the temperature treatment or after a 2-day delay). There was no mortality of control insects (without nematodes).

Preliminary analysis revealed a large effect due to temperature $\times$ salinity, therefore the results for moderate $\left(20^{\circ} \mathrm{C}\right)$ and high $\left(37\right.$ and $\left.39^{\circ} \mathrm{C}\right)$ temperature treatments were analysed separately in order to detect more subtle effects of the other factors. Separate analysis of variance was performed for each of the two isolate sets, which were tested on different occasions. Independent variables were salinity, isolate, exposure time (1-24 h), baiting (immediate or delayed) and, for the $37-39^{\circ} \mathrm{C}$ data sets, temperature.

For the $20^{\circ} \mathrm{C}$ treatment, salinity had a significant effect on $G$. mellonella mortality $(P<0.001$ for each isolate set), with more $G$. mellonella killed by non-saline than by saline sand. This was the only significant effect detected in the analysis; exposure time, isolate and baiting time had

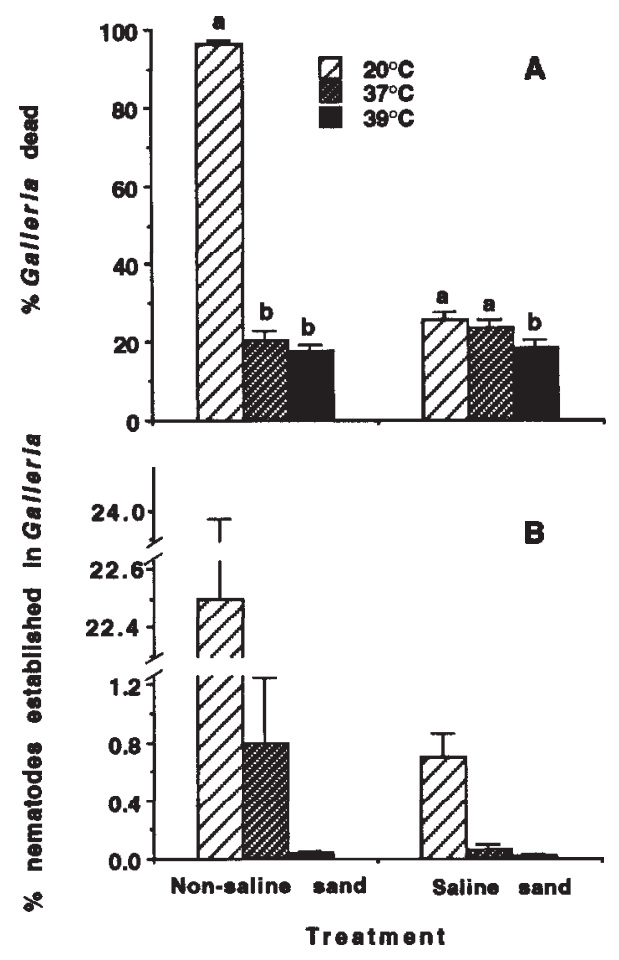

Fig. 3. Infectivity of Heterorhabditis IJs in saline or non-saline sand for Galleria mellonella larvae during a two-day baiting at $20^{\circ} \mathrm{C}$. The Heterorhabditis infested sand had previously been exposed to various temperatures for up to $24 \mathrm{~h}$. A: Percentage of G. mellonella larvae dead. Within sand type, columns accompanied by the same letter are not significantly different $\left(\chi^{2}\right.$ test, $P<0.05$; overall chi-square: non-saline sand: $\chi^{2}=970$, 2 d.f., $P<0.001$; saline sand: $\chi^{2}=9.87,2$ d.f., $P<0.01$ ); $B$ : Percentage of nematodes established in the $\mathrm{G}$. mellonella larvae $($ Bars $=$ SEM $)$.

no significant effect at this temperature in either isolate set.

For sand that had been exposed to 37 and $39^{\circ} \mathrm{C}$, salinity was a less important factor, and was significant for only one of the two isolate sets (Set A, $P<0.05$ ). In this case, more $G$. mellonella were killed in saline sand than in non-saline sand (21.2 compared to $16.5 \%$ ), a reverse of the trend in the $20^{\circ} \mathrm{C}$-treated sand. Temperature also had a significant $(P<0.01)$ effect for Set A: more G. mellonella larvae were killed by IJs-infested sand which had previously been exposed to $37^{\circ} \mathrm{C}$ than in sand that had been exposed to $39^{\circ} \mathrm{C}$ (22 and $15.5 \%$, respectively). Exposure time had a significant effect for both isolate sets. IJs that had been exposed to high temperatures for longer periods resulted in lower G. mellonella mortality: mortality was $27 \%$ following $1 \mathrm{~h}$ heat-exposure and $16 \%$ following $24 \mathrm{~h}$. Baiting time had a significant effect in both isolate 
sets $($ A: $P<0.01$; B: $P<0.001)$, but the nature of the effect was inconsistent. For Set A, immediate baiting resulted in higher bait insect mortality than delayed baiting, while the reverse was true for Set B.

\section{Establishment of nematodes in bait insects}

Dissecting the bait insects confirmed the large effect of salinity and temperature on Heterorhabditis infectivity (Fig. 3B). While $22.5 \%$ of the nematodes established following $20^{\circ} \mathrm{C}$ exposure in non-saline sand, fewer than $1 \%$ established in all other treatments. In non-saline sand, establishment was reduced nearly 30 -fold by exposure to $37^{\circ} \mathrm{C}$ (from $22.5 \%$ at $20^{\circ} \mathrm{C}$ to $0.8 \%$ at $37^{\circ} \mathrm{C}$ ), while in saline sand, it was reduced only 10 -fold (from $0.7 \%$ at $20^{\circ} \mathrm{C}$ to $0.07 \%$ at $37^{\circ} \mathrm{C}$ ). In both saline and nonsaline sand, establishment was further reduced in the $39^{\circ} \mathrm{C}$ treatment (Fig. 3B).

In the case of the high temperature treatments, the majority of the bait G. mellonella that died ( 80 and $95 \%$ in the 37 and $39^{\circ} \mathrm{C}$ treatments, respectively) contained no nematodes when dissected, although they displayed the characteristic appearance of infection with Photorhabdus luminescens. Similarly, many $(69 \%)$ of the dead G. mellonella in the $20^{\circ} \mathrm{C}$ saline sand treatment contained no nematodes. In the $20^{\circ} \mathrm{C}$ non-saline sand, only $7 \%$ of the dead bait $G$. mellonella did not contain any nematodes.

\section{Discussion}

Heterorhabditis IJs of each of the three taxonomic groups tested here were capable of parasitising insects in very saline sand (sand moistened with undiluted sea water). However, their infective ability was greatly reduced compared to those in non-saline sand. IJs were observed to be less active in sea water than in distilled water, and it is likely that reduced mobility due to osmotic stress (Wharton et al., 1983) is the cause of the lowered infectivity. However, interference with host finding ability by constituents of the medium (Thurston et al., 1994) could also contribute to the reduced invasion rate. The ability of IJs to invade insects in sea water-moistened sand is consistent with Poinar's (1993) hypothesis that the genus Heterorhabditis evolved from a marine ancestor, with ancestral types parasitizing arthropods in the littoral zone. However, comparison of six species of entomopathogenic nematodes showed that steinernematids were also capable of infecting insects in sea-water moistened sand, and their infectivity was no more severely affected by salinity than that of the heterorhabditids(Cribbin, unpubl.; Miller, unpubl.).

Sea water clearly protected Heterorhabditis IJs from the damaging effects of high temperature both in aqueous suspension and in sand. In aqueous suspension, the lethal limit for Irish and NWE type nematodes was at least $2^{\circ} \mathrm{C}$ higher in sea water than in distilled water and, in the sand experiment, the infectivity of all isolates was less affected by heating in the saline than in the non-saline medium. Several aquatic invertebrates tolerate supernormal temperatures best at the upper end of the salinity range, and an increase in salinity beyond normal habitat conditions tends to increase heat resistance (Kinne, 1970). In our experiments it is not clear whether IJs were protected from heat damage by the presence of the saline medium during heat exposure, or if protection was conferred before the heating, when the nematodes were transferred from tap water to sea water. In many organisms, prior exposure to one stress confers resistance to another stress by inducing common resistance mechanisms such as synthesis of heat shock proteins (Hoffman \& Parsons, 1991).

In distilled water the two $H$. bacteriophora isolates tolerated higher $\left(39^{\circ} \mathrm{C}\right)$ temperatures than isolates of the NWE and Irish groups $\left(37^{\circ} \mathrm{C}\right)$. This correlates with the original source of the isolates used in the study: The $H$. bacteriophora isolates were from Hungary, which has a continental climate, while the isolates of the NWE and Irish groups were from Ireland, England and The Netherlands, where there is a greater maritime influence. The isolates used here are from locations representative of the distribution of these taxonomic groups in Europe: $H$. bacteriophora primarily has a continental and mediterranean distribution (Deseo \& Miller, 1985; Smits et al., 1991; Griffin et al., 1999), while the NWE and Irish groups mainly occur along the cooler north-west coast of the continent and in Ireland and Britain (Smits et al., 1991; Griffin et al., 1994a; Hominick et al., 1995). Here, however, they frequently occur in sand dunes where temperatures can exceed $40^{\circ} \mathrm{C}$ (Huiskes, 1979), and so the ability to tolerate elevated temperatures may be adaptive for these strains also. The greater similarity between the responses of the NWE and Irish types to each other than to the $H$. bacteriophora isolates corresponds with other findings regarding the biology of the IJs (Griffin et al., 1994b) and the molecular characterization(Smits et al., 1991) of these three taxonomic groups.

We have not determined the maximum temperature tolerated by the Hungarian $H$. bacteriophora isolates; however, they experienced very little mortality following 
$1 \mathrm{~h}$ in aqueous suspension at $39^{\circ} \mathrm{C}$. Moreover, infectivity was unaffected by this treatment, suggesting that sublethal effects were also not important. Despite differences in methodology between our study and others, it would appear that the performance of the Hungarian isolates more closely resembles that of the heat tolerant Israeli IS5 strain than that of the HP88 strain of $H$. bacteriophora (Glazer et al., 1996; Shapiro et al., 1996).

The maximum temperature tolerated by the Irish and NWE isolates was higher in sand (at least $39^{\circ} \mathrm{C}$ ) than in aqueous suspension $\left(37^{\circ} \mathrm{C}\right)$. Similarly, Gray and Johnson (1983) found that $S$. carpocapsae survived for up to two weeks at $40^{\circ} \mathrm{C}$ in soil, while the same species was reported to enter heat coma after $1 \mathrm{~h}$ at $35^{\circ} \mathrm{C}$ in tapwater (Schmiege, 1963). The inferior temperature tolerance in water in our experiments may be explained by the faster rate of heating or lower oxygen availability in that medium. Nematodes in aqueous suspension quickly settle; in contact with the bottom of the vial they would experience a more rapid increase in temperature than IJs in a comparatively large volume of sand. However, the difference in rate of heating was not great, as both media reached the test temperature within $5 \mathrm{~min}$. Although measurements indicated that the water still contained abundant oxygen at the end of the incubation period, the conditions experienced by the IJs at the bottom of the vials may have been locally poorer. While the determination of lethal temperatures for nematodes in aqueous suspension is useful for comparative purposes, it may give an inaccurate indication of a species' tolerance in its natural habitat.

Most of the damage associated with elevated temperatures in sand occurred within $1 \mathrm{~h}$ of exposure; the killing power of IJs dropped from close to $100 \%$ mortality of G. mellonella $\left(20^{\circ} \mathrm{C}\right.$ non-saline treatment) to $27 \%$ after $1 \mathrm{~h}$ of 37 or $39^{\circ} \mathrm{C}$, but a further $23 \mathrm{~h}$ of elevated temperature only reduced killing to $16 \%$. Gray and Johnson (1983) found that the duration of incubation (1 or 2 weeks) did not have a significant effect on the survival of $S$. carpocapsae IJs in soil at temperatures from 20 to $40^{\circ} \mathrm{C}$. Similarly, survival of $H$. bacteriophora in aqueous suspension dropped from 100 to $26 \%$ in the first $2 \mathrm{~h}$ at $37^{\circ} \mathrm{C}$, but there was little further mortality during the next $6 \mathrm{~h}$ at that temperature (Glazer et al., 1996). These findings suggest that once an IJs survives the initial shock of the temperature change, it has a relatively high chance of continued survival, and that the temperature change per se is more detrimental than the continuing exposure.

In general, "washing" increased the infectivity of IJs. For IJs incubated in sea water this could be explained by the restoration of an osmotically more favourable medium (sea water replaced by distilled water). The washing treatment included a 2-day delay between the time that the IJs were washed and the time that their infectivity was tested; this should favour the recovery of IJs that had been subjected to high temperature and/or osmotic shock. However, washing also resulted in increased infectivity following a relatively non-stressful treatment, incubation in distilled water at $20^{\circ} \mathrm{C}$. The reason for this is not clear, but it is unlikely that differences between bait insects or other conditions of the infectivity assays for unwashed and washed nematodes was the cause, as the effect was detected each of the three times the experiment was run.

Following exposure of IJs to high temperatures in sand (both saline and non-saline), most of the dead bait insects contained no living nematodes, even though they were infected with Photorhabdusluminescens. This suggests that the IJs, although capable of invading, had been affected by the heat treatment and failed to develop, as has been reported for Steinernema (Grewal et al., 1994; Henneberry et al., 1996). The proportion of nematodes which can penetrate and establish is a useful parameter for comparing the efficacy of different nematodes under most conditions (Fan \& Hominick, 1991), and was the most suitable parameter in the "aqueous medium" experiment reported here. However, bait insect mortality may be a better measure of infectivity in those rare circumstances when a large proportion of the invading nematodes fails to establish, such as in the "sand" experiment, where up to $95 \%$ of Photorhabdus-killed insects contained no nematodes.

The level of salinity used in the present experiments ( 54 $\mathrm{dS} / \mathrm{m}$ ) is above the tolerance level of all crop plants, and therefore would not be encountered by entomopathogenic nematodes applied inundatively for biocontrol purposes. However, Heterorhabditis has been isolated from sandy beaches devoid of vegetation but with crustaceans present (Amarasinghe et al., 1994); the evidence presented here indicates that, not only would the high salinity of such a shoreline location not preclude infection of hosts there, but it would also protect IJs against possible high temperatures in this unshaded habitat.

\section{Acknowledgement}

We gratefully acknowledge the technical assistance of Ms Fiona Rooney. 


\section{References}

Amarasinghe, L.D., Hominick, W.M., Briscoe, B.R \& REID, A.P. (1994). Occurrence and distribution of entomopathogenic nematodes in Sri Lanka. Journal of Helminthology 68, 277-286.

Deseo, K. V. \& Miller, L.A. (1985). Efficacy of entomogenous nematodes, Steinernema spp., against clearwing moths, Synanthedon spp., in north Italian apple orchards. Nematologica 31, 100-108.

FAn, X.-J. \& Hominick, W.M. (1991). Efficiency of the Galleria (wax moth) baiting technique for recovering infective stages of entomopathogenicrhabditids (Steinernematidae and Heterorhabditidae) from sand and soil. Revue de Nématologie 14, 381-387.

Glazer, I., Kozodoi, E., Hashmi, G. \& Gaugler, R. (1996). Biological characteristics of the entomopathogenic nematode Heterorhabditis sp. IS-5: a heat tolerant isolate from Israel. Nematologica 42, 481-492.

Glazer, I., Liran, N., Poinar, G.O. Jr \& Smits, P.H. (1993). Identification and biological activity of newly isolated heterorhabditid populations from Israel. Fundamental and Applied Nematology 16, 467-472.

Gray, P.A. \& Johnson, D.T. (1983). Survival of the nematode Neoaplectana carpocapsae in relation to soil temperature, moisture and time. Journal of the Georgia Entomological Society 18, 454-460

Grewal, P.S., Selvan, S. \& Gaugler, R. (1994). Thermal adaptation of entomopathogenic nematodes: niche breadth for infection, establishment and reproduction. Journal of Thermal Biology 19, 245-253.

GRIFFIN, C.T. (1993). Temperature responses of entomopathogenic nematodes: implications for the success of biocontrol programmes. In: Bedding, R.A., Akhurst, R.J. \& Kaya, H.K. (Eds). Nematodes for the biological control of insects. Adelaide, Australia, CSIRO. pp. 101-111.

Griffin, C.T., Dix, I., Joyce, S.A., Burnell, A.M.\& Downes, M.J. (1999). Isolation and characterisation of Heterorhabditis spp. from Hungary, Estonia and Denmark. Nematology (in press).

GRIFFIN, C.T. \& DownEs, M.J. (1991). Low temperature activity in Heterorhabditis sp. (Nematoda: Heterorhabditidae). Nematologica 37, 83-91.

Griffin, C.T., JoyCe, S.A., Dix, I., Burnell, A.M. \& Downes, M.J. (1994a). Characterisation of the entomopathogenic nematodes Heterorhabditis (Nematoda: Heterorhabditidae) from Ireland and Britain by molecular and cross-breeding techniques, and the occurrence of the genus in these islands. Fundamental and Applied Nematology 17, 245-253.

Griffin, C. T., Finnegan, M.M. \& Downes, M.J. (1994b). Environmental tolerances and the dispersal of Heterorhabditis: survival and infectivity of European Heterorhabditis fol- lowing prolonged immersion in seawater. Fundamental and Applied Nematology 17, 415-421.

Hara, A.H., Gaugler, R., Kaya, H.K. \& Lebeck, L.M. (1991). Natural populations of entomopathogenic nematodes (Rhabditida: Heterorhabditidae, Steinernematidae) from the Hawaiian islands. Environmental Entomology 20, 211-216.

Henneberry, T.J., Forlow, B.L., Burke, R.A. \& LindeGREN, J.E. (1996). Temperature effects on infection and mortality of Pectinophora gossypiella (Lepidoptera: Belechiidae) larvae by two entomopathogenic nematode species. Environmental Entomology 25, 168-170.

Hoffman, A.A. \& PARsons, P.A. (1991). Evolutionary genetics and environmental stress. Oxford, U.K., Oxford University Press, ix + 284 pp.

Hominick, W.M., Reid, A.P. \& Briscoe, B.R. (1995). Prevalence and habitat specificity of steinernematid and heterorhabditid nematodes isolated during soil surveys of the UK and the Netherlands. Journal of Helminthology 69, 27-32.

Huiskes, A.H.L. (1979). Biological flora of the British Isles. Journal of Ecology 67, 363-382.

KAYA, H.K. (1990). Soil ecology. In: Gaugler, R. \& Kaya, H.K. (Eds). Entomopathogenic nematodes in biological control. Boca Raton, Florida, CRC Press. pp. 93-115.

Kaya, H.K. \& Gaugler, R. (1993). Entomopathogenic nematodes. Annual Review of Entomology 38, 181-206.

Kinne, O. (1970). Temperature — Invertebrates. In: Kinne, O. (Ed.). Marine Ecology. Vol. 1, Part 1. New York, Wiley \& Sons. pp. 407-514.

Kung, S.-P., Gaugler, R. \& Kaya, H.K. (1991). Effects of soil temperature, moisture, and relative humidity on entomopathogenic nematode persistence. Journal of Invertebrate Pathology 57, 242-249.

Molyneux, A.S. (1985). Survival of IJs of Heterorhabditis spp., and Steinernema spp. (Nematoda: Rhabditida) at various temperatures and the subsequent infectivity for insects. Revue de Nématologie 8, 165-170.

MolyneuX, A.S. (1986). Heterorhabditis spp. and Steinernema (= Neoaplectana $)$ spp.: temperature, and aspects of behavior and infectivity. Experimental Parasitology 62, 169180.

POINAR, G.O. JR (1993). Origins and phylogenetic relationships of the entomophilic rhabditids Heterorhabditis and Steinernema. Fundamental and Applied Nematology 16, 333338.

Schmiege, D.C. (1963). The feasibility of using a neoaplectanid nematode for control of some forest pests. Journal of Economic Entomology 56, 427-431.

Shapiro, D.I., Glazer, I. \& Segal, D. (1996). Trait stability and fitness of the heat tolerant nematode Heterorhabditis bacteriophora IS5 strain. Biological Control 6, 238-244.

Smits, P.H., Groenen, J.T.M. \& DE RAAY, G. (1991). Characterization of Heterorhabditis isolates using DNA restriction length polymorphism. Revue de Nématologie 14, 445-453. 
Thurston, G.S., Ni, Y. \& KaYA, H.K. (1994). Influence of salinity on survival and infectivity of entomopathogenic nematodes. Journal of Nematology 26, 345-351.

Wharton, D.A., Perry, R.N. \& Beane, J. (1983). The effect of osmotic stress on behaviour and water content of infec- tive larvae of Trichostrongylus colubriformis. International Journal of Parasitology 13, 185-190. 